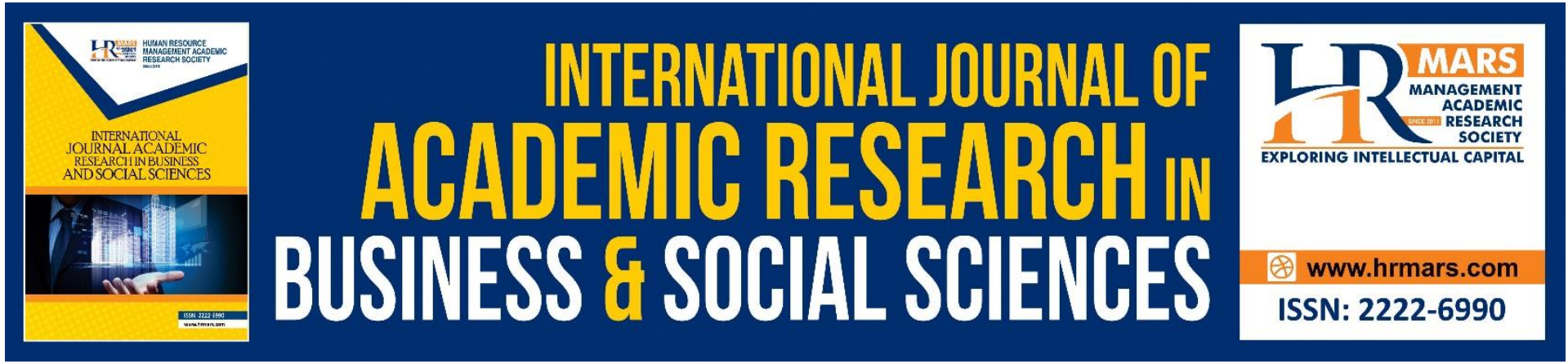

\title{
The Effect of Knowledge, Food Safety and Lifestyle Towards Consumers' Purchase Intention of Halal Food at Restaurants
}

\author{
Muhammad Abdul Adib Abd Aziz, Wan Edura Wan Rashid, Ismah Osman, \\ and Faridah $\mathrm{Hj}$ Hassan
}

To Link this Article: http://dx.doi.org/10.6007/IJARBSS/v11-i7/10579

DOI:10.6007/IJARBSS/v11-i7/10579

Received: 19 May 2021, Revised: 20 June 2021, Accepted: 05 July 2021

Published Online: 23 July 2021

In-Text Citation: (Aziz et al., 2021)

To Cite this Article: Aziz, M. A. A. A., Rashid, W. E. W., Osman, I., \& Hassan, F. H. (2021). The Effect of Knowledge, Food Safety and Lifestyle Towards Consumers' Purchase Intention of Halal Food at Restaurants. International Journal of Academic Research in Business and Social Sciences, 11(7), 10561068.

\section{Copyright: @ 2021 The Author(s)}

Published by Human Resource Management Academic Research Society (www.hrmars.com)

This article is published under the Creative Commons Attribution (CC BY 4.0) license. Anyone may reproduce, distribute, translate and create derivative works of this article (for both commercial and non-commercial purposes), subject to full attribution to the original publication and authors. The full terms of this license may be seen at: http://creativecommons.org/licences/by/4.0/legalcode

Vol. 11, No. 7, 2021, Pg. 1056 - 1068

http://hrmars.com/index.php/pages/detail/IJARBSS

JOURNAL HOMEPAGE

Full Terms \& Conditions of access and use can be found at http://hrmars.com/index.php/pages/detail/publication-ethics 


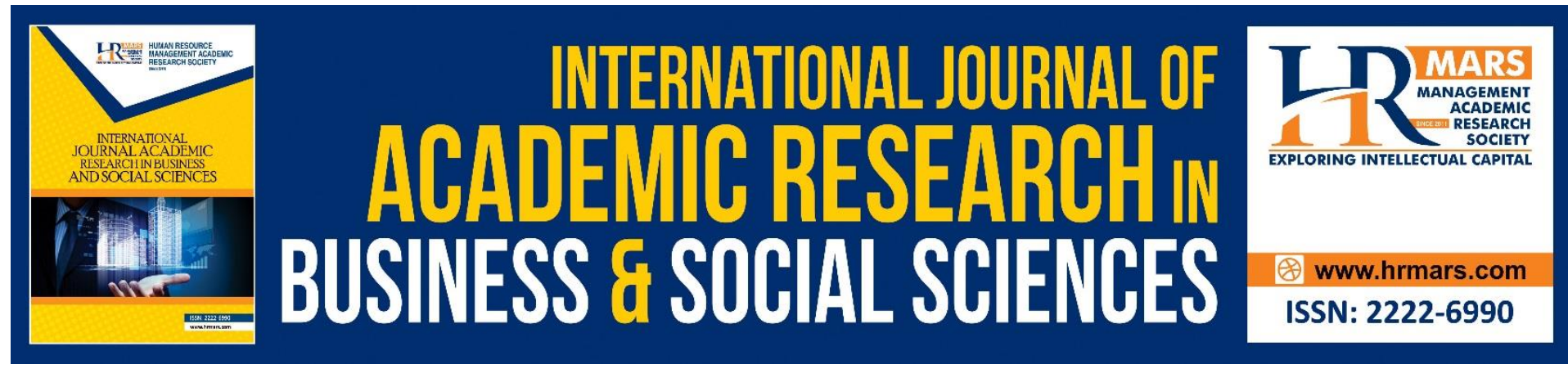

\title{
The Effect of Knowledge, Food Safety and Lifestyle Towards Consumers' Purchase Intention of Halal Food at Restaurants
}

\author{
Muhammad Abdul Adib Abd Aziz¹, Wan Edura Wan Rashid², \\ Ismah Osman ${ }^{3}$, and Faridah $\mathrm{Hj} \mathrm{Hassan}{ }^{4}$ \\ ${ }^{1}$ Universiti Teknologi MARA (UiTM), Faculty of Business Management, Shah Alam, Malaysia, \\ ${ }^{2}$ Universiti Teknologi MARA (UiTM), Institute of Business Excellence, Shah Alam, Malaysia, \\ ${ }^{3}$ Universiti Teknologi MARA (UiTM), Faculty of Business Management, Shah Alam, Malaysia, \\ ${ }^{4}$ Universiti Teknologi MARA (UiTM), Institute of Quality \& Knowledge Advancement (InQKA), \\ Shah Alam, Malaysia
}

Email:maadib1201@yahoo.com,wanedura@uitm.edu.my, ismah817@uitm.edu.my, faridah387@salam.uitm.edu.my

\begin{abstract}
This paper further extends the purchase intention study on Halal food at restaurants by applying the Theory of Planned Behaviour (TPB), thus contributing to the body of knowledge and literature on Halal food study. The main objective of this paper is to investigate the effect of knowledge, food safety, and lifestyle in influencing individuals' intention to purchase Halal food at restaurants. A survey was conducted on 362 Muslim and non-Muslim customers in Klang Valley. The data analyzed made use of the Statistical Package for Social Sciences (SPSS) and Partial Least Square - Structural Equation Modeling (PLS-SEM) using SmartPLS 3.0. The result revealed that knowledge, food safety and lifestyle were significant and positively affected one's intention to purchase Halal food at the restaurant. The implication of this study benefits marketers and restaurant owners or managers as the findings would help them formulate and pursue relevant marketing strategies for their restaurant promotional activities.
\end{abstract}

Keywords: Food Safety, Halal, Lifestyle, Knowledge and Theory of Planned Behaviour.

\section{Introduction}

The word Halal originates from an Arabic word that means 'allowing' or 'permitted' by Islamic law or Syara'. Halal is defined as permissible and lawful, while the opposite of Halal is Haram, which is defined as prohibited. There is another term, "Shubhah" which means questionable; for example, when a person does not know the ingredients and how it is processed, the food then falls under the "Shubhah" category. In Islam, it is advisable to avoid things that are "Shubhah". The use of Halal is commonly related to food wherein Halal point of view, the food that is meant for consumption must be free from pork or alcohol, and animals such as cattle, chicken, and lamb should be slaughtered by following the Islamic principles (Rahman, Asrarhaghighi \& Rahman, 2015). Apart from that, another category 
"Thoyyiban" is defined as cleanliness, safety, nutrition, good quality and authenticity (Shaikh, 2006; Mariam, 2006). In further deliberation, Halal food is consumable but if it has health implications, it is considered non-Thoyyiban, particularly junk food.

Halal food products have grown in popularity among non-Muslims worldwide, as the term Halal is consistent with what is good, healthy, safe, and of high quality. Malaysia announced its intention years ago to become a global centre for the manufacturing and distributing of Halal goods and services. The government believes that more commercial opportunities are available with Halal products and services. Hence, Malaysia has developed the Halal Industry Development Corporation (HDC) to show its commitment to play a leading role in the Halal industry. Malaysia, as a Muslim majority country, has a sizable home market for Halal food. Malaysia is well-positioned to serve as an international Halal food hub for the branding, processing, and marketing of Halal goods to Muslim populations due to the recognition given worldwide as a modern Muslim nation.

Additionally, Malaysia developed its Halal standard (MS 1500:2004) in 2004, satisfying both Muslim community criteria as well as international health and safety norms. As a result, Malaysia regards its certification standard as a competitive advantage and expects it will be acknowledged as the worldwide standard's baseline. To reinforce all rules and processes, the Ninth Malaysia Plan includes a section on the growth of the Halal business (2006-2010). One of the primary goals is to develop Malaysia into a centre for Halal product manufacturing and distribution as well as to modernize the essential infrastructure to attract additional traders and investors. Additionally, with the growing Muslim population globally, which now numbered around 1.8 billion, the Halal food business has enormous potential.

Furthermore, the term Halal does not only refer solely to food, but also cosmetics, pharmaceuticals, apparels, financial services, and even trip packages. From a global point of view, the expenditure in lifestyle sectors was worth USD2.1 trillion in 2017 and projected to be worth $\$ 3$ trillion by 2023. Meanwhile, Muslims globally spent USD1.3 trillion on food and beverages, representing $61.9 \%$ of the total of $\$ 2.3$ trillion of Muslim consumers' global spending in 2017. The spending on Halal food by Muslims is expected to grow to $\$ 1.86$ trillion by 2023, a growth of $6.1 \%$ from 2017 to 2023 (Reuters, 2019). This highlight the demand for Halal food that is trending all over the world. With the growing awareness of Halal food in Malaysia, the Malaysian government continues to encounter troubling difficulties with the idea of Halal, in particular misconduct and unethical behaviour; including hygienic practices, certificate modification, and certificate expiration (Shaari, Ottot, \& Kermin, 2013). In addition, the lack of awareness and information about the benefits of the Halal procedure leads nonMuslim customers not to practise Halal food consumption daily (Golnaz et al., 2010). Therefore, the knowledge and awareness of Halal products and services still lack and confuse the consumers (Maichum, Parichatnon \& Peng, 2017). Thus, it is important to investigate the consumer behaviour on Halal products. The fundamental Theory of Planned Behaviour applied in this study is to understand the knowledge, food safety and lifestyle towards consumers' intention to purchase Halal food at restaurants.

\section{Literature Review \\ Purchase Intention}

Intention is described as a statement of a person's motivation to engage in a particular behaviour (Ajzen, 2002). It is assumed to reflect the motivating variables that impact behaviour, and it indicates how far someone is willing to go and how much effort one intends to expend to achieve the behaviour (Ajzen, 1991). The concept of purchase intention may 
apply to understand an individual who has the intention to purchase Halal food at the restaurant. The intention has come before an individual behaviour, which is deciding to buy the product. The Theory of Planned Behaviour, attitude, subjective norms, and perceived behaviour control are the determinants commonly used to investigate consumer behaviour (Ajzen, 1991). When a person has a buying intention to dine at a restaurant, the person is almost certainly implicated in the business purchasing behaviour. The more vigorous the intention to engage in the behaviour, the more likely its performance should be. Intention varies throughout time, and as the time interval between actions increases, the correlation between intention and action decreases (Ajzen \& Fishbein, 1977). As shown by the TPB model, the intention to conduct an inevitable action increases as the individual's attitude and subjective norms become more favourable (Ajzen, 2002). Davis, Bagozzi, and Warshaw (1989) as well as Taylor and Todd (1995) discovered that intention is a significant predictor of consumer behaviour. Consumers' intention to purchase Halal food increases when they think they have more influence over buying them (Khairi et al., 2012).

\section{Knowledge}

Knowledge is considered an attribute that reflects the consumer's decision to purchase a product that could be influenced by product properties and user experience (Kim et al., 2016). It is one of the major factors influencing consumers' decision in purchasing a product (Othman, Shaarani \& Bahron, 2016). There are three categorizations of knowledge: subjective knowledge, objective knowledge and prior experience (Brucks, 1985; Piha et al., 2018). Subjective knowledge refers to what the consumers perceive that they know. In other words, it is called self-rated knowledge. It represents the confidence of an individual about his knowledge. The low level of subjective knowledge results in a lack of confidence (Chryssochoidis, 2000; Padel \& Foster, 2005). Objective knowledge is what the consumers know. Meanwhile, prior experience is defined as what the consumers have experienced before (Brucks, 1985). O'Donoghue, Perchoux, Mensah, Lakerveld, van der Ploeg and Nazare (2016) defined consumer knowledge as storing of information about the products in memory or identifying through thoughts, making the consumer find out the more convenient or easier way in the purchasing process. A consumer finds product information through his related memory or experience to purchase the product.

Previous studies showed that knowledge is important in creating the behaviour of actual consumer purchase intention, especially towards Halal products such as Halal food (Derahman, Takrim \& Rahman, 2017; Othman et al., 2016; Maichum et al., 2017; Simanjuntak \& Dewantara, 2014). Derahman's et al. (2017) findings showed that awareness which is the knowledge or understanding of a subject or situation, is one of the determinants in consumers' purchase intention. Another study by Othman et al. (2016) on the level of knowledge of the food industries reported that the level of knowledge is still good. Therefore, this study suggested the following hypothesis:

H1: Knowledge has a positive effect on consumers' intention to purchase Halal food at restaurants.

\section{Food Safety}

According to the Australian Institute of Food Safety (2019), food safety is defined as the practice of handling, preparing and storing food which lowers the risk of people getting 
sick from foodborne illnesses. Food safety also covers the familiarity of consumers on the ingredients, quality and safety of the food. Wandel (1997) stated that consumers are serious to know what kind of food they consume, hence they commonly get information from the labels. Thus, knowledge on food ingredients is important for consumers to make purchase decision.

When relating food safety with Halal, its principles strictly preserve the hygiene and cleanliness of Halal food. These principles are increasingly being used as guideline in food safety globally. The strict process of preparing Halal food and the procedures to control the overall operations is important in order to maintain the hygiene and safety of the food for consumers' consumption. This can be also known as Good Manufacturing Practice (GMP) and Good Hygiene Practice (GHP) in Malaysia, which are the manufacturing and quality control procedures to ensure the products are consistently manufactured according to the specification and prescriptions given in the Malaysian Standard (MS1514:2012) regulated by the government. Moreover, the Malaysian Standard on Halal Food (MS 1500:2019) complies with both the international standards of Good Manufacturing Practices and Good Hygiene Practices. The former also prescribes practical guidelines for the food industry on the preparation and handling of Halal food (including nutrient supplements) based on quality, sanitary and safety considerations and serves as a basic requirement for food products and food trade or business in Malaysia.

Past studies showed the importance of food safety in consumers' consumption and purchase decision. Wallace, Yee, Yeung and Morris (2005) stated that consumers are equally concerned on the physical risk in their food, whereby their concern begins from the farming stage, namely on the types of chemicals, fertilizers, additives and preservatives used to produce the food. In a study by Phan and Mai (2016), they stated that it is essential for all fast-food restaurants in Binh Duong province to focus on the level of food safety which is the first consideration of students' purchase intention through the study. In fact, food safety is also a fundamental principle to attract customers and to build the reputation for any food restaurants. Another study by Quantaniah, Noreina, and Syakinah (2013) found that nonMuslim students are more concerned on health, safety and quality aspects in their food selection. The study also concluded that religious values, health, safety and quality are significant factors in explaining the consumption of food products in Malaysian societies. Next is a study done by Ismail et al (2016) which found that there is significant relationship between food safety and Halal purchase intention among Muslim consumers. Padel and Foster (2005) added that food safety can become an indicator as consumers' motivation towards purchasing products and the relationship between food safety, attitudes and purchase intention has not been formally modelled yet. Therefore, this study suggested the following hypothesis:

H2: Food safety has a positive effect towards consumers' intention to purchase Halal food at restaurants.

\section{Lifestyle}

There are several definitions of lifestyle. The term lifestyle refers to a person's way of living and has been used primarily for examining the living patterns and mobility of various social classes (Bei, 2000). Lifestyle is a pattern of life that is expressed in a state of psychographic (Kotler \& Armstrong, 2005). Lazer (1963) defined lifestyle as a systemic concept, attributing this special model to the gathering of people and their development in a 
dynamic society. Another definition of lifestyle is to show how people live, how they spend money, and how they allocate time (Mowen \& Minor, 2002).

Lifestyle is also described as a consumer's way of living by laying emphasis on values and actions in a social culture (Wells \& Prensky, 1996). There are two concepts of lifestyle, the first is the model of lifestyle and the second is the market segmentation, which every element in the system such as activities, interests, opinions and demographic variables being used to understand the whole market (Plummer, 1974). Furthermore, there are two methods to apply lifestyle into the market segmentation, which are general lifestyle research and specific lifestyle research. General lifestyle research focuses on the personal activities, interests and opinions of consumers in their daily lives, whereas specific lifestyle research emphasizes on the responses of consumers pertaining to a certain product. Hawkins, Roger and Kenneth (2000) regarded lifestyle as the embodiment of self-concept and considered it to be shaped collectively by past experience, intrinsic features and the circumstances at the time, referring to how people live their lives and generate different lifestyles through different ways of living.

Previous studies done by Nora and Minarti (2016); Lin and Shih (2012) as well as Jayasree (2011) prove that lifestyle has an influence towards purchase intention. One of the studies was carried out with a survey towards a total of 289 female university students wearing hijab, in order to find out their perception towards hijab fashion. As a result, lifestyle also significantly influenced purchase intention when attitude acted as mediating variable (Nora \& Minarti, 2016). While the research focussed on female respondents, Lin and Shih (2012) focussed on finding determinants of purchase intention between university students, distributed questionnaires and got a feedback from 449 respondents from ten universities. As a result, even though it is found that lifestyle influences purchase decision of university students, their different type of lifestyle will still be affecting their decision whether to purchase an item or not. Another study conducted by Jayasree (2011) used Activity, Interest, Opinion (AIO) measures in order to identify the lifestyle dimensions of consumers. The study used survey method by distributing questionnaire to a total of 711 respondents. This study confirmed that there is a significant relationship between consumers' lifestyle and the product's brand that is used by them. Below is the following hypothesis suggested for this study.

H3: Lifestyle has a positive effect towards consumers' intention to purchase Halal food at restaurants.

\section{Research Framework}

Based on the literature review above, several hypotheses have been postulated. Referring to the hypotheses, this research has suggested a framework based on TPB as shown in Figure 1. The figure illustrates the consumers' intention to purchase Halal food at restaurants as dependent variable and three independent variables which are knowledge, food safety and lifestyle which determine consumers' purchase intention of Halal food at restaurant. 


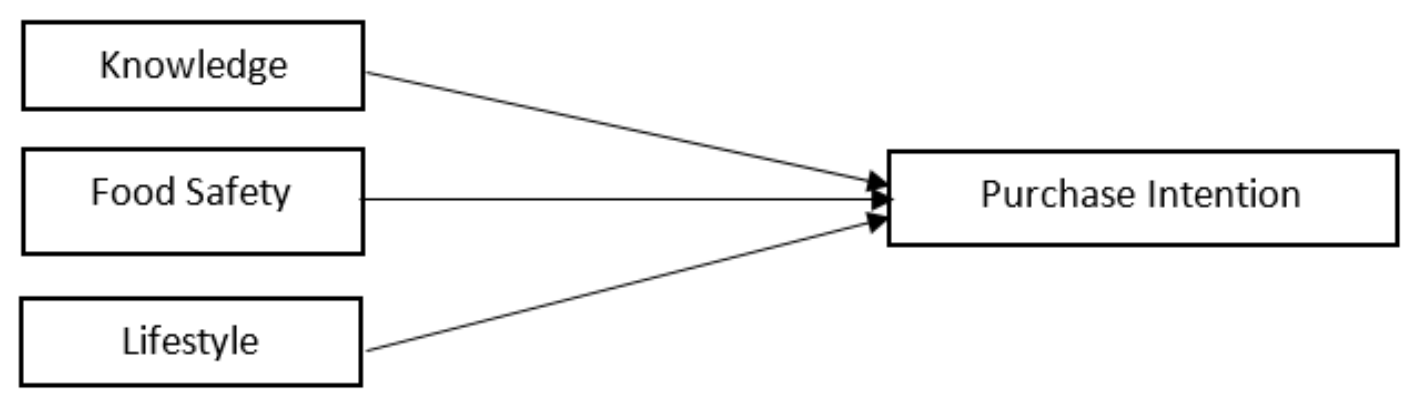

Figure 1: Proposed Research Framework

\section{Methodology}

The purpose of this study was to predict the effects of knowledge, food safety and lifestyle that influence consumers' inclination to purchase Halal food at restaurants in Klang Valley. The purposive sampling used to identify a sample from 420 working adults who had eaten Halal food at a restaurant. A total of 420 questionnaires were distributed to respondents, and 362 questionnaires were returned, a response rate of $86.12 \%$. In this study, most of the respondents were female (51.4\%), and the majority of the respondents were from age 31 to 40 years (32\%) and 21 to 30 years old (25.4\%). In addition, most of the respondents were Malays (62.4\%) and Chinese (23.8\%), they have Bachelor's degree as their highest education background (51.9\%) and have a salary range of RM3001 to RM4500 (30.1\%).

This study adopted the quantitative approach. In addition, a self-administered questionnaire was chosen as the main research instrument. Meanwhile, a 10-point Likert scale, ranging from 1 to 10 showing 1 for "strongly disagree", 2 for "disagree", 3 for "moderately disagree", 4 for "slightly disagree", 5 for "mildly disagree", 6 for "mildly agree", 7 for "slightly agree", 8 for "moderately agree", 9 for "agree", and 10 for "strongly agree", were used to measure the proposed constructs in this study. The scales were used to assess knowledge, food safety and lifestyle adapted from Shaari et al., (2013); Rahman, Asrarhaghighi and Rahman, (2015); Jamal and Shaifuddin, (2015); Khalek and Ismail, (2015); Maichum et al., (2017). The data were analyzed using the Statistical Package for the Social Sciences (SPSS) and Partial Least Squares - Structural Equation Modeling (PLS-SEM).

\section{Results and Discussion}

\section{Measurement Model Analysis}

Convergent validity is the degree to which a measure correlates positively with another measure of the same construct (Ramayah \& Rahbar, 2013). Establishing convergent validity involves satisfying the conditions imposed upon indicators' loadings, composite reliability, and the average variance extracted (AVE) (Lee \& Kozar, 2008). Based on an established rule of thumbs, the indicators' loadings of an item should exceed the threshold value of 0.60 (Chin, 2010; Gholami et al., 2013), while the cut-off point for both the composite reliability and AVE is 0.70 and 0.50 respectively (Hair et al., 2017). The following Table 1 indicates the factor loading in the range of 0.843 to 0.967 being greater than 0.60 and explained that all items were applicable to this study. The AVE and composite reliability of knowledge (0.872), food safety (0.838), lifestyle (0.878) and purchase intention (0.923) were greater than 0.07 which explained that the variables have high internal consistency of the study. 
Table 1: Outer Loading, AVE and Composite Reliability of Constructs

\begin{tabular}{|c|c|c|c|c|}
\hline Constructs & Items & Loadings & AVE & CR \\
\hline \multirow{5}{*}{ Knowledge } & KN1 & 0.939 & \multirow{5}{*}{0.872} & \multirow{5}{*}{0.972} \\
\hline & KN2 & 0.919 & & \\
\hline & KN3 & 0.934 & & \\
\hline & KN4 & 0.941 & & \\
\hline & KN5 & 0.937 & & \\
\hline \multirow{4}{*}{ Food Safety } & FS1 & 0.843 & \multirow{4}{*}{0.838} & \multirow{4}{*}{0.954} \\
\hline & FS2 & 0.931 & & \\
\hline & FS3 & 0.936 & & \\
\hline & FS4 & 0.948 & & \\
\hline \multirow{3}{*}{ Lifestyle } & L1 & 0.935 & \multirow{3}{*}{0.878} & \multirow{3}{*}{0.956} \\
\hline & L3 & 0.935 & & \\
\hline & L4 & 0.940 & & \\
\hline \multirow{3}{*}{ Purchase Intention } & PI1 & 0.955 & \multirow{3}{*}{0.923} & \multirow{3}{*}{0.973} \\
\hline & $\mathrm{PI2}$ & 0.967 & & \\
\hline & PI3 & 0.959 & & \\
\hline
\end{tabular}

Following that, discriminant validity was used to determine the degree to which items were distinguished between constructs by assessing the model's correlations. To ensure discriminant validity is not affected, items should load more strongly on their own construct. The AVE shared between each concept and its measure should be bigger than the variance shared between the construct and another construct (Compeau, Higgins \& Huff, 1999). To determine the discriminant validity of the concept, a Fornell and Lacker (1981) criterion was used to assess the correlation between the construct and the AVE values.

Table 2: Fornell-Larcker's Criterion

\begin{tabular}{lllll}
\hline & $\mathbf{1}$ & $\mathbf{2}$ & $\mathbf{3}$ & $\mathbf{4}$ \\
\hline Food Safety & $\mathbf{0 . 9 1 5}$ & & & \\
Knowledge & 0.710 & $\mathbf{0 . 9 3 4}$ & & \\
Lifestyle & 0.863 & 0.658 & $\mathbf{0 . 9 3 7}$ & $\mathbf{0 . 9 6 1}$ \\
Purchase Intention & 0.866 & 0.734 & 0.937 & \\
\hline
\end{tabular}

\section{Structural Model Analysis}

Assessing the structural model involves evaluating $\mathrm{R}^{2}$, beta and the corresponding $\mathrm{t}$ values (Hair, Hult, Ringle \& Sarstedt, 2014). Chin (2010) suggested to do bootstrapping procedure with 1000 resamples to gain the t-values. In addition, researchers should also report predictive relevance $\left(Q^{2}\right)$ and effect sizes (f2) (Hair et al., 2014). The results of the structural model analysis in this study are shown in Table 3.

Based on Table 3, all constructs have significant positive relationship with consumers' purchase intention. Knowledge has a beta value of 0.176 , $t$-value of 3.118 and $p<0.05$, while food safety has a beta value of $0.127, t$-value of 8.085 and $p<0.05$, and lifestyle has a beta value of $0.711, t$-value of 18.099 and $p<0.05$. All three constructs explained 90.5 percent of the variance in purchase intention and Hair et al. (2014) suggested that the $R^{2}$ value is considered substantial. Among the constructs, lifestyle was the strongest predictor of purchase intention with a beta value of 0.711 , followed by knowledge $(0.176)$ and food safety 
(0.127). Therefore, all the three hypotheses $(\mathrm{H} 1, \mathrm{H} 2, \mathrm{H} 3)$ were accepted as those constructs have significant positive relationship with purchase intention.

Next is assessing the effect size $\left(\mathrm{f}^{2}\right)$. This measure evaluated the changes in $\mathrm{R}^{2}$ values when a specified exogenous construct is omitted from the model that can be used to evaluate whether the omitted construct has a substantive impact on the endogenous constructs. Cohen (2008) stated that the guideline for assessing $f^{2}$ is the values of $0.02,0.15$ and 0.35 , representing small, medium, and large effects of the exogenous latent variable respectively. Based on the results in Table 3, it can be observed that lifestyle has a large effect size, while knowledge has a medium effect size and food safety has a small effect size.

Finally, examining $Q^{2}$ value as an addition to evaluate the magnitude of $R^{2}$ values as a criterion of predictive accuracy (Hair et al, 2017). $Q^{2}$ value is obtained by applying the blindfolding procedure for a certain omission distance (D). This procedure is a sample reuse technique that omits every data point in endogenous constructs indicators and estimates the parameter with remaining data points (Chin, 2010; Henseler, Ringle, \& Sinkovics, 2009). The omitted data points are considered as missing value and treated accordingly when running the PLS-SEM algorithm using mean value replacement and the results then are used as inputs for $Q^{2}$ measure (Hair et al, 2014). Table 3 shows the $Q^{2}$ value for the structural model using blindfolding technique. Based on Table 3 , the $Q^{2}$ value are 0.839 , which is more than 0 , thus, suggesting a sufficient predictive relevance.

Table 3: Results of Structural Model Analysis

\begin{tabular}{|c|c|c|c|c|c|c|c|c|c|}
\hline Hypothesis & Relationships & $\begin{array}{l}\text { Beta } \\
\text { value }\end{array}$ & $\begin{array}{l}\text { Std } \\
\text { Dev. }\end{array}$ & $\begin{array}{l}\mathrm{T}- \\
\text { statistics }\end{array}$ & $\begin{array}{l}P \text { - } \\
\text { value }\end{array}$ & $\mathbf{R}^{2}$ & $f^{2}$ & $\mathbf{Q}^{2}$ & Decision \\
\hline $\mathrm{H} 1$ & & 0.176 & 0.041 & 3.118 & 0.002 & \multirow{3}{*}{0.905} & 0.159 & \multirow{3}{*}{0.839} & Accepted \\
\hline $\mathrm{H} 2$ & $\mathrm{FS}-->\mathrm{PI}$ & 0.127 & 0.022 & 8.085 & 0.000 & & 0.038 & & Accepted \\
\hline H3 & L --> PI & 0.711 & 0.039 & 18.099 & 0.000 & & 1.340 & & Accepted \\
\hline
\end{tabular}

\section{Discussion}

From the result of this study, knowledge is found to affect intention to purchase Halal food positively. This shows that consumers prefer to know the food and place they dine in, hence they have to have more information on the food and the restaurant; that there exists higher intention for them to dine in at the restaurant. The findings support those of other Halal-related studies (Khairunnisa \& Hendratmi, 2019; Fahmi, 2017; Derahman et al., 2017; Maichum et al., 2017), which showed knowledge has a positive influence on purchase intention. Apart from that, food safety also found to affect consumers' purchase intention positively. The result shows that consumers consider and are cautious about what they eat, whether the food is safe for them to consume. The findings are aligned with several other studies ( Maichum et al., 2017; Ismail, Nik, Ahmad \& Sidek, 2016; Majid, Sabir \& Ashraf, 2015; Mohtar, Amirnordin \& Haron, 2014) that food safety has positive and significant influence on purchase intention. Lastly, lifestyle was found to have a significant positive effect with consumer purchase intention. It suggested that consumers only purchase Halal food if it fits their lifestyle. This is supported by several previous studies (Lin \& Shih, 2012; Nora \& Minarti, 2016; Jayasree, 2011), that lifestyle has significant and positive influence on purchase decisions. 


\section{Conclusion and Recommendation}

The major purpose of this study is to investigate the effects of knowledge, food safety, and lifestyle in influencing individuals' intention to purchase Halal food at restaurants. The findings of this study revealed that knowledge, food safety, and lifestyle have significant and favourable effects on purchase intention. The research shows that restaurant owners and marketers should develop a business strategy and implement effective marketing techniques for their businesses to encourage people to dine in. Government agencies, such as the Department of Islamic Development Malaysia (JAKIM) and the Halal Development Corporation (HDC) are also urged to strengthen their Halal certification programs. While for the restaurant owners, they must ensure emphasis on the safety of the food they provide. Thus, it has to align with Halal certification's mission to safeguard food safety and quality. In terms of future research, it is recommended that researchers expand their geographical scope to other states in Malaysia or to rural areas in order to have a better understanding of customers' Halal food purchasing behaviour.

\section{References}

Ajzen, I. (1991) The Theory of Planned Behavior. Organizational Behavior and Human Decision Processes, 50, 179-211.

Ajzen, I. (2002) Perceived Behavioral Control, Self-Efficacy, Locus of Control, and the Theory of Planned Behavior. Journal of Applied Social Psychology, 32, 665-683.

Ajzen, I., and Fishbein, M. (1977) Attitude-behavior relations: A theoretical analysis and review of empirical research. Psychological Bulletin, 84, 888-918.

Australian Institute of Food Safety. (2019) What is Food Safety? Retrieved from https://www.foodsafety.com.au/blog/what-is-food-safety.

Bei, L. T. (2000) The Whitepaper on Lifestyle: A Report of the 2000 Survey on Taiwanese Consumption Habits. Taipei City: Business Weekly Publications.

Brucks, M. (1985) The Effects of Product Class Knowledge on Information Search Behavior. Journal of Consumer Research, 1-16. https://doi.org/10.1086/209031.

Chin, W. W. (2010). How to write up and report PLS analyses. In Esposito Vinzi, V., Chin, W.W., Henseler, J., \& Wang, H. (Eds.), Handbook of partial least squares: Concept, methods and applications. Springer-Verlag, Berlin, Germany.

Chryssochoidis, G. (2000) Repercussions of consumer confusion for late introduced differentiated products, European Journal of Marketing, 34(5/ 6), 705722.

Cohen, E. (2008). Designing and Conducting Mixed Methods Research. Research on Social Work Practice 18(5): 527-530.

Compeau, D. R., and Higgins, C. A. (1991) A social cognitive theory perspective on individual reactions to computing technology. ICIS 1991 Proceedings. 55. https://aisel.aisnet.org/icis1991/55.

Davis, F. D., Bagozzi, R. P., and Warshaw, P. R. (1989) User acceptance of computer technology: A comparison of tow theoretical models, Management Science, Vol. 35, No.8, pp.982-1003.

Derahman, Z., Takrim, K. B., and Rahman, Y. A. (2017) Customers' intention to eat at halal certified restaurant using SEM PLS. Politeknik and Kolej Komuniti Journal of Social Sciences and Humanities, 1, pp. 9-23.

Fahmi, S. (2017) Halal labelling effect on muslim's consumers attitude and behaviour. 10.2991/icoi-17.2017.26. 
Fornell, C., and Larcker, D. F. (1981). Evaluating Structural Equation Models with Unobservable Variables and Measurement Error. Journal of Marketing Research, 18(1), 41-54.

Gholami, R., Sulaiman, A. B., Ramayah, T., and Molla, A. (2013). Senior managers' perception on green information systems (IS) adoption and environmental performance: Results from a field survey. Information \& Management, 50(7), 431-438.

Golnaz, R., Zainalabidin, M., Nasir, M. S., and Eddie, F. C. C. (2010) Non-Muslims' awareness of Halal principles and related food products in Malaysia. International Food Research Journal, 17.

Hair, J. F., Tomas, G. M. H., Ringle, C. M., \& Sarstedt, M. (2017). A Primer On Partial Least Squares Structural Equation Modeling (PLS-SEM), 2nd Edition. SAGE Publications, California.

Hair, J., Hult, G. T. M., Ringle, C. M., and Sarstedt, M. (2014). A Primer on Partial Least Squares Structural Equation Modeling (PLS-SEM). USA: Sage publications, Inc.

Hawkins, D. I., Roger J. B., and Kenneth, A. C. (2000) Consumer Behavior: Building Marketing Strategy, 8/e, McGraw Hill Company.

Henseler, J., Ringle, C. M., and Sinkovics, R. R. (2009). The use of Partial Least Squares Path Modeling in International Marketing. Advances in International Marketing, 20(8), 277-320.

Ismail, I., Abdullah, N. A., Ahmad, Z., and Sidek, L. (2016). Halal Principles and Halal Purchase Intention Among Muslim Consumers.

Jamal, A., and Sharifuddin, J. (2015) Perceived value and perceived usefulness of halal labeling: The role of religion and culture. Journal of Business Research, 68. 10.1016/j.jbusres.2014.09.020.

Jayasree, K. (2011). Lifestyle - A tool for understanding buyer behavior. AIMA J. Manage. Res. 1. 1-25.

Khairi, M. O., Nik, K. N. M., Gaboul, A. I., and Fatihya, M. A. A. (2012) The Direct Effects of Halal Product Actual Purchase Antecedents among the International Muslim Consumers. American Journal of Economics, 87-92.

Khairunnisa, B. V., and Hendratmi, A. (2019) The Influence of Product Knowledge and Attitude Towards Intention in Mudharabah Funding Products in Sharia Banks in Mataram. The 2nd International Conference on Islamic Economics, Business, and Philanthropy (ICIEBP) Theme: "Sustainability and Socio Economic Growth", KnE Social Sciences, pp. 663-677. DOI 10.18502/kss.v3i13.4239.

Khalek, A. A., and Ismail, S. H. S. (2015) Why are we eating Halal - Using the Theory of Planned Behavior in Predicting Halal food consumption among Generation $Y$ in Malaysia. International Journal of Social Science and Humanity, 5 (7).

Kim, Y., Yun, S., Lee, J., and Ko, E. (2016) How consumer knowledge shapes green consumption: An empirical study on voluntary carbon offsetting. International Journal of Advertising, 35(1): 23-41.

Kotler, P., Armstrong, G., and Cunningham, M. H. (2005) Principles of marketing. Toronto: Pearson Prentice Hall.

Lazer, W. (1963) Life Style Concept and Marketing. Proceedings of the American Markering Association, pp.130-139.

Lee, Y., \& Kozar, K. (2008). An empirical investigation of anti-spyware software adoption: a multitheoretical perspective. Information \& Management, 45(2), 109-119. 
Lin, L., and Shih, H. (2012) The Relationship of University Student's Lifestyle, Money Attitude, Personal Value and their Purchase Decision. International Journal of Research in Management, 1(2).

Maichum, K., Parichatnon, S., and Peng, K. (2017) The Influence of Attitude, Knowledge and Quality on Purchase Intention towards Halal Food: A Case Study of Young Non-Muslim Consumers in Thailand. IRA-International Journal of Management \& Social Sciences (ISSN 2455-2267), 6(3), 354-364. doi:http://dx.doi.org/10.21013/jmss.v6.n3.p3.

Majid, M., Sabir, D., and Ashraf, T. (2015) Consumer Purchase Intention towards Halal Cosmetics \& Personal Care Products in Pakistan. Global Journal of Research in Business \& Management, 1(1), 45-53.

Retrieved from http://www.gpcpublishing.org/index.php/gjrbm/article/view/82

Mariam, A. L. (2006) Current Issues on Halal Food [Online]. Kuala Lumpur. http://www.mift.org.my/Current\%20Issues\%20in\%20Halal\%20Food.ppt. [Accessed 20/10/08].

Mohtar, N. M., Amirnordin, N. A., and Haron, H. (2014) Ayamas Food Corporation Sdn. Bhd: A Study on the Factors of Consumer Behaviour towards Halal Product Selection. Procedia-Social and Behavioral Sciences, 121, 166-185.

Mowen, J. C., and Minor, M. (2002) Perilaku Konsumen Jilid 1, Edisi Kelima (translation), Erlangga, Jakarta.

Nora, L. and Minarti, N.S. (2016) The role of religiosity, lifestyle, attitude as determinant purchase intention. The II International Multidisciplinary Conference, 1(1), 135-149.

O'Donoghue, G., Perchoux, C., Mensah, K., Lakerveld, J., Vazn der Ploeg, H., and Nazare, J. A. (2016) A Systematic Review of Correlates of Sedentary behaviour in Adults Aged 1865 years: A Socio-ecological Approach. BMC Public health, 16(1). DOI:10.1186/S12889016-2841-3.

Othman, B., Shaarani, S. M., and Bahron, A. (2016) Evaluation of knowledge, halal quality assurance practices and commitment among food industries in Malaysia. British Food Journal, 118(8) pp. $2033-2052$.

Padel, S., and Foster, C. (2005) Exploring the gap between attitudes and behaviour: Understanding why consumers buy or do not buy organic food. British Food Journal, 107 (8), pp.606-625. https://doi.org/10.1108/00070700510611002.

Phan, T., and Mai, P. (2016). Determinants Impacting Consumers? Purchase Intention: The Case of Fast Food in Vietnam. International Journal of Marketing Studies. 8. 56. 10.5539/ijms.v8n5p56.

Piha, S., Pohjanheimo, T., Lähteenmäki-Uutela, A., Křečková Kroupová, Z., and Otterbring, T. (2016) The effects of consumer knowledge on the willingness to buy insect food: An exploratory cross-regional study in Northern and Central Europe. Food Quality and Preference, 70. 10.1016/j.foodqual.2016.12.006.

Plummer, J. T. (1974) The Concept Application of Life Style Segmentation, Journal Marketing, 38(1), pp.33-37.

Quantaniah, N. A., Noreina, and Syakinah, N. (2013). Selecting Halal Food : A Comparative Study Of The Muslim And Non-Muslim Malaysian Student Consumer. 2nd International Conference on Technology Management, Business and Entrepreneurship (ICTMBE 2013): Enhancing Business Capabilities Through Technology Innovation and Entrepreneurship. 
Rahman, A. A., Asrarhaghighi, E., and Rahman, A. S. (2015) Consumers and Halal cosmetic products: knowledge, religiosity, attitude and intention. Journal of Islamic Marketing, 6. 148-163. 10.1108/JIMA-09-2013-0068.

Ramayah, T., and Rahbar, E. (2013). Greening the environment through recycling: An empirical study. Management of Environmental Quality: An International Journal, 24(6), 782-801.

Shaari, J. A. N., Ottot, H., and Kermin, M. F. (2013) Halal; organic; and preservative: marketing concept for bread industry. Proceedings of Annual Paris Business and Social Science Conference Crowne Plaza Hotel, Republique, 4-5 July, Paris, pp. 27-39.

Shaikh, M. S. M. S. (2006) Aspects of food safety from the islamic perspective. In Shaikh Mohd, S.M.S \& Azrina, S. (Ed.). Food and Technological Progress an Islamic Perspective, Kuala Lumpur: MPH.

Taylor, S., and Todd, P. (1995) Decomposition and Crossover Effects in the Theory of Planned Behavior: A Study of Consumer Adoption Intentions. International Journal of Research in Marketing, 12, 137-56.

Reuters, T. (2019), State of the Islamic Economy Report 2018/19. Toronto, Ontario, Thomson Reuters.

Wandel, M. (1997). food labelling from a consumer perspective, British Food Journal, 99(6), MCB University Press.

Wallace, M. S., Yee, R., Yeung, M. W., and Morris, J. (2005). Food safety: Building consumer trust in livestock farmers for potential purchase behaviour. British Food Journal, 841854.

Wells, W. D., and Prensky, D. (1996) Consumer Behavior, John Wiley and Sons Inc. 